\title{
AEROSPACE MARKETING MANAGEMENT
}




\section{AEROSPACE MARKETING MANAGEMENT}

\section{Manufacturers $\bullet$ OEM $\bullet$ Airlines $\bullet$ Airports - Satellites $\bullet$ Launchers}

by

PHILIPPE MALAVAL

Toulouse Business School (ESC Toulouse), France and

CHRISTOPHE BÉNAROYA

Business Conseil, France

Springer Science+Business Media, $L L C$ 


\section{Library of Congress Cataloging-in-Publication Data}

Malaval, Philippe.

Bénaroya, Christophe.

[Marketing aéronautique et spatial. English]

Aerospace Marketing Management. Manufacturers - OEM - Airlines - Airports Satellites - Launchers / by Philippe Malaval and Christophe Bénaroya

p.cm.

Translation of: Marketing aéronautique et spatial.

Includes bibliographical references and index.

ISBN 978-1-4613-5377-5 ISBN 978-1-4615-1065-9 (eBook)

DOI 10.1007/978-1-4615-1065-9

Copyright (C2002 Springer Science+Business Media New York

Originally published by Kluwer Academic Publisher in 2002

Softcover reprint of the hardcover 1st edition 2002

All rights reserved. No part of this publication may be reproduced, stored in a retrieval system or transmitted in any form or by any means, mechanical, photocopying, recording, or otherwise, without the prior written permission of the publisher, Springer Science+Business Media, LLC

Printed on acid-free paper.

This book was first published in France in October 2001, Pearson Education France, Paris. Translated and published with permission of Pearson Education France. 


\section{CONTENTS}

Preface

\section{Chapter 1}

Marketing in the Aeronautics and Space Industry

1. The aeronautics and space sector environment

1.1 Characteristics of the aeronautics and space sector 1

1.2 Market deregulation 2

1.3 The role of regulatory organizations: FAA, DGAC, CAA, IATA 3

The organizations which control air transport 5

2. The marketing approach 9

2.1 The rise of marketing 9

2.2 The two facets of marketing $\quad 11$

2.3 An essential part of companies and organizations $\quad 12$

$\begin{array}{ll}2.4 \text { A set of methods with wide-ranging applications } & 13\end{array}$

3. The role of marketing in the aeronautics and space industry 14

3.1 The growing importance of marketing in the aeronautics and space sector $\quad 14$

$\begin{array}{ll}3.2 \text { Different types of marketing } & 15\end{array}$

$\begin{array}{ll}\text { 3.3 Marketing in the aeronautics and space supply chain } & 18\end{array}$

3.4 Recent marketing trends in aeronautics $\quad 20$

\section{Chapter 2}

The Individual and Organizational Purchase 23

1. The individual purchase 23

1.1 Factors influencing the buying behavior 23

The child as influencer $\quad 25$

Senior marketing $\quad 26$

1.2 The buying process 30

2. The organizational purchase $\quad 34$ 
2.1 The buying center $\quad 34$

$\begin{array}{ll}2.2 \text { Buying phases } & 37\end{array}$

"Make or Buy ?", the example of the Super Transporter: from Super Guppy to A300-600ST

2.3 Different situations

2.4 The behavior of professional buyers 44

$\begin{array}{ll}2.5 \text { Bidding } & 47\end{array}$

2.6 E-procurement and the development of the marketplaces 49

3. Case study: the aircraft constructor's approach to the airline's buying center

3.1 First action level (1): the customer airline $\quad 52$

3.2 Second action level (2): air traffic regulatory bodies $\quad 55$

3.3 Third action level (3): airports $\quad 56$

3.4 Fourth action level (4): passengers and citizen groups 56

4. Case study: Airing's approach to the buying center of the Sultan of M

5. Purchase marketing

$\begin{array}{ll}\text { 5.1 The different conceptions of purchase marketing } & 61\end{array}$

$\begin{array}{ll}5.2 \text { Purchase marketing objectives } & 61\end{array}$

5.3 Means of action $\quad 62$

Purchase marketing at EADS 66

\section{Chapter 3}

Business Marketing Intelligence $\quad 75$

1. The information system 75

Dassault Aviation: Increasing Falcon customer satisfaction by using an efficient information system $\quad 76$

2. Market surveillance: active listening $\quad 78$

$\begin{array}{ll}2.1 \text { The different types of surveillance } & 79\end{array}$

$\begin{array}{ll}2.2 \text { Setting up surveillance } & 80\end{array}$

Docland: Aerospatiale-Matra's information and documentation center (EADS)

3. Information sources $\quad 82$

3.1 Main information sources $\quad 83$

$\begin{array}{ll}3.2 \text { Information protection } & 87\end{array}$

Market studies made by Boeing and Airbus $\quad 88$

4. The main types of studies $\quad 95$

4.1 Qualitative studies $\quad 96$

$\begin{array}{ll}\text { 4.2 Quantitative studies } & 97\end{array}$

The international tourism study: a key analysis for airline destination strategy

4.3 Permanent and ad hoc studies 
From the Airbus $A 3 X X$ project to the A380: the primordial role of studies

\section{Chapter 4}

Market Segmentation and Positioning

1. Segmenting a market

1.1 The objectives of segmentation

The segmentation of the satellite market

1.2 The main segmentation methods

2.1 Positioning objectives

Four examples of positioning: Singapore Airlines, Air France,

Swissair, American Airlines

Two further examples: Virgin Atlantic and easyJet 138

2.2 Setting up positioning 139

Lufthansa Technik: positioning based on customer success 143

\section{Chapter 5}

Marketing and Sales Action Plan

1. The marketing plan 147

1.1 Part one: the analysis 149

1.2 The objectives 152

1.3 The means or action plan $\quad 154$

2. The sales action plan 156

2.1 The objectives of the sales action plan 157

2.2 How the sales action plan is carried out 158

2.3 An example of the contents of a sales action plan 159

\section{Chapter 6}

Innovation and Product Management 161

1. The learning curve 161

2. The product life cycle 163

2.1 Phases of the life cycle 164

2.2 Applying the life cycle concept 165

2.3 The characteristics of each life cycle phase $\quad 167$

3. Managing the product portfolio 168 
3.1 The BCG model $\quad 169$

An analysis of the Airbus and Boeing product portfolios 172

$\begin{array}{ll}3.2 \text { The McKinsey model } & 174\end{array}$

$\begin{array}{ll}3.3 \text { The Little model } & 175\end{array}$

3.4 Marketing and management of the product portfolios 176

The Bombardier niche strategy 177

4. Managing the product range 178

$\begin{array}{ll}\text { 4.1 The characteristics of the range } & 178\end{array}$

The CFM International engine range 180

5. Managing innovation 182

Latécoère's innovation: on-board video systems 182

The different generations of a product: military aircraft 184

5.1 In-house innovations: the "push" strategy 186

Weber Aircraft: innovation at the heart of the offer 187

5.2 Innovations from outside: the "pull" strategy 189

The evolving range of Rolls-Royce Trent engines 191

$\begin{array}{ll}5.3 \text { Product development phases } & 191\end{array}$

5.4 The conditions for successful development 194

Innovation at Spot Image: Spot Thema 196

6. Innovation, the key to development of the A380 wide-body jet 198

$\begin{array}{ll}6.1 \text { Analysis of the market and the range } & 198\end{array}$

$\begin{array}{ll}6.2 \text { Taking into account customer's expectations } & 199\end{array}$

$\begin{array}{ll}6.3 \text { Producing a solution } & 200\end{array}$

6.4 Innovation in the cockpit $\quad 201$

6.5 Production innovation to reduce costs 202

$\begin{array}{ll}\text { 6.6 The involvement of industrial partners } & 203\end{array}$

$\begin{array}{ll}6.7 \text { Cabin fittings } & 205\end{array}$

$\begin{array}{ll}6.8 \text { Future versions of the A380 } & 207\end{array}$

Chapter 7

Marketing of Services 211

1. The characteristics of services 211

1.1 Intangibility 211

On-line information: a service to increase maintenance efficiency 212

1.2 "Perishability" and stock-impossibility 213

1.3 Inseparability 214

1.4 Variability 214

Spot Image: a service with multiple applications 216

2. Different categories of services 218

3. Professional services 220

$\begin{array}{ll}3.1 \text { Services which are required by law and regulations } & 221\end{array}$

3.2 More general services linked to management and strategy 222 
3.3 The aeronautical "marketplaces": a new type of service from MyAircraft to AirNewco

3.4 Services linked to the production process

3.5 Sales related services

3.6 Technical and commercial, global services

Servair: a global service fulfilling the expectations of airlines and their passengers

4. Consumer services: transport and tourism 230

Qualiflyer, airlines serving customers 231

Taking care of unaccompanied minors $\quad 232$

An example of a health service: MEDjet International 233

The exemplary service quality of Thai Airways 235

5. Focus on the freight market 238

5.1 The evolution of the freight market: expansion of the "integrated" carriers 240

5.2 The reaction of the cargo airline companies 243

\section{Chapter 8}

Pricing Policy

1. Factors involved in pricing 245

1.1 External constraints 246

1.2 Internal constraints 250

The business plan or forecasting financial profitability 251

2. Pricing approaches $\quad 254$

2.1 Cost-based pricing 254

Example of a modulated pricing policy for domestic Air France flights 256

2.2 Value-based pricing 256

Helicopter engine manufacturers: taking into consideration the market and after sales in the pricing policy

2.3 Bidding 262

3. Pricing strategies 263

3.1 The skimming strategy 263

3.2 The penetration strategy 264

Charter on-line business aircraft $\quad 265$

3.3 Flexibility strategies 266

3.4 Yield management 266

Bold easyJet: Internet, yield management and non-conformism 268

3.5 The development of the "gray market" 270

4. Price-adjustment policy 270

4.1 Adjusting the conditions of sale 270

4.2 The leasing 272

4.3 The development of fractional ownership on the business aircraft market 274

The NetJets (from Executive Jet) fractional ownership program 274 


\section{Chapter 9}

Selecting Distribution Channels and Sales Team Management

1. Logistics

2. Choosing a distribution system

2.1 Choosing an external solution

2.2 Choosing multi-brand or exclusive distributors

Breitling's selective distribution

2.3 Selecting partners and managing the network

The development of e-ticketing

3. Managing the sales point: adjusting supply to demand 286

3.1 The basis of the merchandising approach

Travel agency merchandising

3.2 Merchandising objectives

A special application of merchandising: managing spare parts

4. Direct channel: the role of the sales representative

4.1 Communication

4.2 Pre-sales: prospecting

4.3 Sales presentation and negotiation

4.4 After-sales: the follow-up

The recent evolution of sales representatives

4.5 Information feedback

The sale of aircraft

5. Managing the sales team 296

$\begin{array}{ll}5.1 \text { Defining objectives } & 297\end{array}$

$\begin{array}{ll}5.2 \text { Choosing the structure } & 298\end{array}$

5.3 The size of the sales team $\quad 299$

5.4 Recruiting sales representatives $\quad 299$

$\begin{array}{ll}5.5 \text { Supervising the team } & 300\end{array}$

$\begin{array}{ll}5.6 \text { Remunerating sales representatives } & 301\end{array}$

5.7 Sales representatives: motivation, training and career management 304

Chapter 10

Project Marketing

1. The specific nature of project marketing 307

$\begin{array}{ll}1.1 \text { High financial stakes } & 307\end{array}$

The Beijing Capital International Airport 308

$\begin{array}{ll}1.2 \text { A "one-off" project } & 309\end{array}$

$\begin{array}{ll}1.3 \text { Generally predefined buying procedures } & 310\end{array}$

1.4 A generally discontinuous supplier-customer relationship 312

2. Building demand 313

2.1 Identifying the customer's latent demand 313 
2.2 Helping to formulate dissatisfaction $\quad 313$

$\begin{array}{ll}2.3 \text { Developing a solution } & 314\end{array}$

An example of constructing demand: building industry and airports $\quad 314$

$\begin{array}{ll}2.4 \text { Drafting a solution } & 316\end{array}$

3. Customer intimacy $\quad 317$

$\begin{array}{ll}3.1 \text { The depth of the interaction } & 317\end{array}$

3.2 The extent of the interaction 318

4. Influencing specifications $\quad 320$

4.1 Intervening upstream of the deal 320

Industrial partnerships to win bids: the tender concerning missiles for the British Eurofighter

4.2 Intervening in the deal

Services at the very heart of the creative bid strategy: application to the military market

\section{Chapter 11}

Communication Policy

1. Different types of communication 327

$\begin{array}{ll}1.1 \text { The objectives of communication } & 328\end{array}$

1.2 The four main types of communication $\quad 330$

2. The communication plan 337

2.1 Determination of targets and budgets 337

2.2 Setting up the communication plan 341

Chapter 12

Selecting Media $\quad 347$

1. Trade shows 347

$\begin{array}{ll}\text { 1.1 The specific nature of trade shows } & 347\end{array}$

$\begin{array}{ll}1.2 \text { Exhibiting at a show } & 352\end{array}$

The Paris Air Show - Le Bourget: the leading international aeronautics and space show $\quad 354$

1.3 The different stages of participating in a show 356

2. The trade press 358

$\begin{array}{ll}2.1 \text { Main characteristics } & 358\end{array}$

Aviation Week \& Space Technology 358

$\begin{array}{ll}2.2 \text { Resources and tools } & 364\end{array}$

3. The Internet 366

Boeing and the Internet $\quad 369$

4. Direct marketing 371

4.1 The objectives of direct marketing 371

$\begin{array}{ll}4.2 \text { The different tools } & 372\end{array}$

5. Television, billboards and radio 373 
5.1 Television

An original operation: Airbus Beluga "Delacroix"

5.2 Radio

5.3 Billboards

6. Lobbying

Lobbying the regulatory organizations

Lobbying for the Airbus Military Company A400M project

7. Public relations and sponsoring

7.1 Public relations

7.2 Sponsoring

8. Sales promotion

\section{Chapter 13}

\section{Brand Management}

$\begin{array}{ll}1.1 \text { Brand mechanisms } & 400\end{array}$

1.2 Brand functions for the company 404

1.3 Brand functions for the customer 406

Aeronautics and space brands and performance facilitation 413

2. Special characteristics of the industrial brand 413

2.1"Purchaseability" levels of the industrial brand 414

$\begin{array}{ll}2.2 \text { The visibility strategy } & 415\end{array}$

2.3 Airbus: "Setting the Standards" 418

3. Industrial brands classification 424

3.1 According to the use of goods $\quad 424$

3.2 According to international brand policy 424

3.3 According to brand origins 425

4. Visual identity code, logos and slogans 436

$\begin{array}{ll}4.1 \text { Logos } & 436\end{array}$

$\begin{array}{ll}4.2 \text { Slogans } & 439\end{array}$

4.3 Jingles 441

4.4 Visual identity code 441

5. Latécoère: technical partnership and its own products 442

5.1 The rise of Latécoère $\quad 442$

5.2 Latécoère, technical performance facilitator brand 444

$\begin{array}{ll}5.3 \text { Sales performance facilitation } & 447\end{array}$

6. Zodiac: managing a brand portfolio by sector 447

$\begin{array}{ll}6.1 \text { History } & 447\end{array}$

6.2 Zodiac today 449

6.3 Brand policy $\quad 450$ 
Chapter 14

Building loyalty: Maintenance, Customer Training and Offsets 455

1. Maintenance 455

A key to aircraft safety $\quad 461$

1.1 The different forms of maintenance $\quad 462$

1.2 Maintenance: a tool for the marketing-mix 466

1.3 Maintenance: a tool for the marketing information system 467

Airbus' after-sales marketing function: 4 main objectives 469

2. Customer training 472

Pilot training: a major and essential expense $\quad 472$

2.1 Different training objectives $\quad 473$

2.2 The contents of training $\quad 474$

Training, an essential part in the Airbus strategy 475

2.3 The main types of training 481

GDTA: cutting-edge training 482

3. Offset, a business tool $\quad 484$

3.1 Offset: a means of payment $\quad 484$

3.2 A business argument 487

Chapter 15

Alliance Strategies $\quad 491$

1. Traditional forms of company development 491

2. Specific objectives of alliances 492

2.1 Financial objectives 493

2.2 Marketing and sales objectives $\quad 494$

2.3 The international political stakes $\quad 498$

3. Different forms of alliances 498

3.1 Tactical alliances 501

3.2 Strategic alliances while maintaining the company's initial identity 502

Star Alliance: a worldwide air network $\quad 505$

SkyTeam: a new worldwide air network $\quad 507$

3.3 Strategic alliances with creation of a specific structure 512

The CFM International alliance 512

Starsem: an alliance for a reliable and competitive space transport system $\quad 516$

Sea Launch: from the sea into space 521

3.4 From alliance to merger $\quad 522$

From GIE Airbus Industrie to the integrated company EADS 523

Eurocopter: once a joint-venture, today a subsidiary $\quad 525$

Bibliography $\quad 529$

Subject index 


\section{PREFACE}

This book presents an overall picture of both business to business and business to consumer marketing in the aeronautics and space sector. Designed to be a practical handbook, it deals with all of the basic marketing concepts and tools, both from an operational and strategic point of view.

Aeronautics and Space Management is the first marketing manual entirely illustrated with examples taken from the aerospace sector: parts suppliers, aircraft builders, airlines, helicopter manufacturers, aeronautics service providers, airports, defense and military companies, satellites integrators, and space launchers, among others.

Organized so as to allow the reader to select those chapters that are most useful to him or her, it does not require prior in-depth marketing knowledge. While it is not exhaustive, particularly concerning the buying process or segmentation, it does address the most recent marketing trends (e-marketing, one-to-one marketing, customer orientation, project marketing...). Accessible to a wide public, this book was written in particular for executives working in the field as well as for students from Engineering and Business Schools.

The main marketing tools are discussed from purchase marketing, market surveillance and surveys, quality management and norms on the one hand, to trade shows, the trade press, direct marketing, public relations, lobbying, maintenance, customer training and offsets on the other. There is also a chapter focusing on branding strategy and brand management, in particular their role in facilitating customer performance, as well as a chapter on the project marketing approach. Last but not least, Chapter 15 presents the alliance strategies of the leading aeronautics manufacturers, part suppliers and airlines. 
For their encouragement, trust and the information they have graciously provided, we would like to thank the companies mentioned in the book and in particular:

- Aeromexico: José Diaz de la Rivera

- Aéroports de Paris: Jacques Reder, Isabelle de Villeneuve, Catherine Bénétreau, Corine Bokobza-Servadio

- Aéroport de Toulouse-Blagnac: Michel Gay

- Air \& Cosmos: Jean-Pierre Casamayou

- Air \& Space Europe: Jean-Pierre Sanfourche

- Air Cargo News: Geoffrey Arend

- Air France: Laurent Clabé-Navarre, Benoît Guizard, Georges Rochas, Pierre-Yves Reville, François Roppe

- Airbus / EADS: Michel Guérard, Roland Sanguinetti, Claire Labedaix, Gilles Meric, Bruno Piquet, David Jennings, Richard Carcaillet, JeanFrançois Lasmezas, Bernard Bousquet, Philippe de Saint-Aulaire, Philippe Girard, Didier Lenormand, Françoise Soulier, Jérôme Verzat, Jean-Bernard Oresve, Anne Carrere, Daniel Baubil, Jean-Marc Thomas, Patrick Roger, Alain Vilanove

- Alcatel Space Industries: Thierry Deloye, Dominique Murat, Christiane Grimal, Rémy Sergent

- Alcatel: Caroline Mille

- AlliedSignal Aerospace: Bettina Pei-Ching Li

- American Airlines: Michael Gunn, Talcott J. Franklin, Phyllis J. Sawyers

- ATR: Carlo Logli, Bernard Fondo, Jacques Dronnet

- Aviapartner: Hervé Bonnan

- Aviation International News: Charles Alcock

- Aviation Sales Company: Dale Baker

- Aviation Week \& Space Technology: Mark A. Lipowicz, Pierre Sparaco

- BAe Systems: Richard H. Evans, Nina Collins

- Bell (Textron): Dave Wyatt, Jenny Jackson, Robert N. Kohn

- BFGoodrich Aerospace: David L. Burner, Marshall O. Larsen

- Boeing: Philip M. Condit, Dan Kays

- Bombardier / Canadair: Yvan Allaire, Catherine Chase, Leo Knaapen

- Breitling: Nathalie Frésard

- Cathay Pacific: Nicholas Reynolds

- CFM International / Snecma: Pierre Bry, Sylvie Béamonte, Olivier

Laroche, Nadia Zaïdi, Jean-Paul Rouot, M. Hucher, Jacques Geneste

Civil Aviation Authoriy, CAA: Malcom Field, Douglas Andrews

- Dassault Aviation: Nicolas Renard 
- Direction Générale de l'Aviation Civile, DGAC: Jacques Girerd, BrunPotard, Philippe Beghelli

- easyJet: Toby Nicol, Samatha Day

- École Nationale Supérieure de l'Aéronautique et de l'Espace (Supaero):

Pierre Jeanblanc, Chantal Gauthier, Joël Daste

- Eros: Denis Taieb

- Euresas: Sabine Kramer, William Gibson

- Eurocopter: Alain Journeau, Jean-Louis Boireau

- Euromissile: Jean Thyrard

- Explorer Consulting Company: Laurent Husson

- Farnborough: Maureen Symester, Linda Lloyd, Lindsey Hart

- Federal Aviation Administration, FAA: Norm Simenson

- Fedex: David J. Bronczek

- Foster and Partners: Norman Foster, Katy Harris

- GDTA: Jean-Luc Bessis

- GEIA: Dan Heinemeier, Jim Serafin, Mary Petitt, Michael Dooner

- General Electric: John F. Welch, David L. Calhoun

- Gore-Tex: Édouard Frignet des Préaux

- Institut Aéronautique et Spatial: Hervé Schwindenhammer, Michel Chauvin, Alain Riesen

- Jane's Airport Review: Alan Condron

- Latécoère: François Junca, Jean-Pierre Robert, Philippe Martin, Raphaël Bolzan

- Lockheed Martin: James Fetig, Lee Whitney

- Lucas Aerospace (TRW): Joseph T. Gorman, William K. Maciver

- Lufthansa Technik: Aage Duenhaupt, Angelika Albert-Graffert, Claudia Ungeheuer

- MartinBaker America: Bill Harrison, B.A. Miller

- Medjet: Jeffrey Tolbert, Sam Jackson, Stan Bradley, Debbie L. Ebner

- Messier-Dowty: Philippe Merle

- Motorola: Christian Ollivry

- Pechiney Aerospace: Caroline Lenglin, Jean-Claude Nicolas

- Rockwell-Collins: Jack Barbieux

- Rolls-Royce: John Purcell, John Crocker, Richard Deeks

- Royal Air Maroc: Asmâa Oudghiri, Nezha Alaoui, Karina Marmech

- Sea Launch: Terrance Scott, Glenn Anderson

- Sennheiser: Karlheinz Koinzack

- Servair: Jean-Luc Neirynck, Nathalie Hedin, Sandrine Audivert,

- Smiths Industrie: Jennifer Villarreal

- Spot Image: Alain Hirschfeld

- Starsem: Claire Coulbeaux, Romain Lavault

- Swissair: Michael Eggenschwiler 
- Thai Airways: Pascale Baret

- Thalès Detexis (ex-Thomson-CSF): Gérard Bouy, Jean-Paul Perrier, Jean-Luc Pomier, Carole Caubet

- Turbomeca: Guillaume Giscard d'Estaing, Jean-Marc Soulier

- Virgin Atlantic: Charlotte Tidball

- Weber Aircraft: William Chase

- Zodiac: Dominique Puig.

We would like to thank the "Delegates" of the Aerospace MBA of the Toulouse Business School (ESC Toulouse) and our students who have indirectly contributed to this book thanks to their remarks and suggestions, and in particular:

- Nathalie Brun, Jun Cao, Robin Calot, Nicolas Coma, Olivier Courrèges, Thierry Debergé, Vincent Ducamin, Esmeralda Herrera, Julien Joncquiert, J. C. Jong, Thomas Lelièvre, Benoît Machefert, Olivier Malavallon, Gaël Maugendre, Hakim Messoussa, Laurence Milhade, Guillaume Pellegrino, Thomas Pelon, Göknur Pilli, Olivier Royer-Manoha, Xavier-Alexandre Scalbert, Vincent Varnier.

We would also like to thank of course Toulouse Business School (ESC Toulouse) for its support and in particular:

- Hervé Passeron, Andres Atenza, Jean-Luc Guiraud, Jonathan Winterton, Denis Lacoste,

- Florence Lévy and the whole Documentation Center,

- Jean-Luc Bouchot and his team.

Thanks to Geoffrey Staines of Pearson/Publi-Union as well as Monika Neumann for authorizing this American edition. Thanks to Marika Seletti and Adrian Pavely for the translating of the English version.

We are deeply grateful to our parents and our respective families. Thanks in particular to Christine for her kind understanding and support. Thanks to Isabelle and to my children Guilhem, Bertrand, Robin and Marion. 